\title{
Influence of phosphate buffered saline on the bond strength of endodontic cement to dentin
}

\author{
Bruna Casagrande Cechella ${ }^{1}$, Josiane de Almeida ${ }^{1}$, Mara Cristina Santos Felippe ${ }^{1}$, \\ Cleonice da Silveira Teixeira ${ }^{1}$, Eduardo Antunes Bortoluzzi ${ }^{1}$, Wilson Tadeu Felippe ${ }^{1}$
}

${ }^{1}$ Universidade Federal de Santa Catarina - UFSC, School of Dentistry, Department of Endodontics, Florianópolis, SC, Brazil

Received for publication: March 16, 2015 Accepted: May 28, 2015

Correspondence to: Bruna Casagrande Cechella Rua Duque de Caxias, 549 Centro, Içara CEP: $88820-000$ SC, Brasil Phone: +55(0)48 37219549 Fax:+55(0)48 37219542 E-mail: bru_casa@hotmail.com

\begin{abstract}
Aim: To analyze the influence of exposure and time of exposure to phosphate buffered saline (PBS) on the push-out bond strength (BS) of Biodentine to dentine. Methods: Eighty 2-mm-thick dentin discs were obtained from transversal sections of human teeth roots. The space of the canal was enlarged using \#2-\#5 Gates-Glidden burs to obtain 1.3-mm-diameter standardized cavities. The discs were immersed in 17\% EDTA followed by $1 \% \mathrm{NaOCl}$ and dried. The spaces of the canals were filled with Biodentine and the samples were divided into 2 groups $(n=40)$ according to the storage: G1: exposure to moistened cotton pellet; G2: exposure to PBS. After 30 min, 1, 3 and 28 days, 10 samples of each group were subjected to the push-out test. Data were analyzed using ANOVA and Tukey test $(p<0.05)$. Results: The specimens exposed to PBS had lower BS $(p<0.05)$, except for the 1-day period $(p=0.6017)$. In specimens of Group 1 the BS increased up to 3 days $(p<0.05)$. In specimens in Group 2, the BS increased from 30 min to 1 day ( $<<$ $0.0001)$ and remained stable up to 3 days $(p=0.9876)$. At 28 days, a significant decrease was observed in the BS values of both groups $(p<0.05)$. Conclusions: The exposure of Biodentine to PBS led to lower BS values. In general, the BS increased gradually up to 3 days and reduced at 28 days.
\end{abstract}

Keywords: endodontics; dental materials; dentin.

\section{Introduction}

When sealing communications between the pulp cavity and the periodontium, repair materials should remain in place when submitted to functional pressures or condensation of restorative and root canal filling materials ${ }^{1}$.

Currently, mineral trioxide aggregate (MTA) is one of the most used repair cements. Several studies have demonstrated that the bond strength (BS) of MTA to dentin ranges from 3.55 to $4.67 \mathrm{MPa}^{2-4}$.

However, the BS of MTA increases with time $\mathrm{e}^{3,5}$ and is greater when the material is maintained in contact with phosphate buffered saline (PBS) (4.21 MPa -7.14 $\mathrm{MPa})^{2-3}$.

Recently, Biodentine (Septodont, Saint Maur des Fossés, France) was introduced as a new repair material alternative to $\mathrm{MTA}^{6}$. The powder is mainly composed of tricalcium silicate, calcium carbonate and zirconium oxide. The liquid contains water, calcium chloride (used as setting accelerator) and a modified polycarboxylate (superplasticising agent) ${ }^{7-8}$. Biodentine is presented by the manufacturer as a "bioactive dentin substitute" and its indications are similar to the aggregate. 
The BS of Biodentine to dentin ranges from 7.18 to 8.79 $\mathrm{MPa}^{4,9}$, values higher when compared to MTA, even if exposed to different solutions such as sodium hypochlorite, chlorhexidine and saline solution ${ }^{4}$.

Similar to MTA, the exposure of Biodentine to $\mathrm{PBS}^{10}$ and Hank Balanced Saline Solution (HBSS) ${ }^{11}$ leads to precipitation of hydroxyapatite and interacting with dentin in PBS, this material provides formation of extensions that penetrate into the dentinal tubules ${ }^{12-13}$. However, the BS of Biodentine to dentin after contact with PBS is not known. Therefore, the aim of this study was to analyze the influence of exposure and time of exposure to PBS on the push-out bond strength of Biodentine to dentin. The null hypothesis was that the exposure of Biodentine to PBS would improve its push-out bond strength to dentin over time.

\section{Material and methods}

Forty single-rooted, extracted human teeth were used under a protocol approved by the Ethics Committee of the Federal University of Santa Catarina, Brazil (protocol number 232.508).

The procedures were performed as described by ReyesCarmona et $\mathrm{al}^{2}{ }^{2}$ and de Almeida et $\mathrm{al}^{3}$. The crowns were removed, and the middle thirds of the roots were sectioned transversally by using a water-cooled low-speed ISOMET diamond saw (Buehler, Lake, Bluff, NY, USA) in order to obtain 2-mm-thick sections. In each section, the canal space of was enlarged using \#2-\#5 Gates-Glidden burs, to obtain 1.3-mm-diameter standardized cavities. The sections were immersed in 17\% EDTA for 3 min followed by $1 \%$ sodium hypochlorite for the same time. They were then immediately washed in distilled water and dried. The cavities were filled with Biodentine (Septodont, Saint Maur des Fosseés, France), which was mixed following the manufacturer's recommendations.

The cement mixture was placed into cavities with a MTA carrier and compacted with pluggers. Excess material was trimmed from the surface with a scalpel. All specimens were examined under a microscope (10X) in order to discard any cracks, defects or gaps between the material and dentin walls.

After filling, the root sections were randomly divided into 2 groups $(\mathrm{n}=40)$ : exposure to moistened cotton pellet (group 1) or immersed in $15 \mathrm{~mL}$ of PBS (Dermus, Florianópolis, $\mathrm{SC}, \mathrm{Brazil} ; \mathrm{pH}=7.2$ ) (group 2). The root sections were stored at $37{ }^{\circ} \mathrm{C}$ for $30 \mathrm{~min}, 1,3$ and 28 days. The PBS solution was replaced every 5 days.

\section{Push-out test}

After the experimental periods, 10 samples of each group were randomly chosen and submitted to the push-out test. The samples were placed in a steel holder that was screwed to an aligning device that held it centered below a steel piece with a cylindrical punch. This aligning device was then fixed to an Instron machine (Model 4444; Instron Corp, Canton, MA, USA) and a vertical force was placed directly on the cement in each sample with the Instron probe moving at $0.5 \mathrm{~mm} / \mathrm{min}$. The maximal force applied to the cement before displacement was recorded in Newtons $(\mathrm{N})$. The pushout value in $\mathrm{MPa}$ was calculated from force $(\mathrm{N})$ divided by area in $\mathrm{mm}^{2}\left(1 \mathrm{MPa}=1 \mathrm{~N} / \mathrm{mm}^{2}\right)$.

\section{Statistical Analysis}

Mean and standard deviations were determined for each group. The Shapiro-Wilk test was used to check the normality of data distribution. The data were statistically analyzed by one-way ANOVA and Tukey's HSD post hoc test $(\mathrm{p}<0.05)$.

\section{Results}

The mean values of push-out strength (MPa) for each group, in different experimental periods, are shown in Table 1. Bond strength was significantly greater in Group 1 ( $\mathrm{p}<$ $0.05)$, except for the 1-day period $(\mathrm{p}=0.6017)$. Both groups presented increase of BS from $30 \mathrm{~min}$ to 3 days. In the specimens from Group 1 the BS increased at each period up to 3 days $(\mathrm{p}<0.05)$. However, there was significant reduction at 28 days $(\mathrm{p}=0.0005)$, similar to the 1-day period $(\mathrm{p}=0.9941)$. For the specimens in contact with PBS (Group $2)$, the BS increased from 30 min to 1 day $(\mathrm{p}<0.0001)$ and remained stable up to 3 days $(\mathrm{p}=0.9876)$. At 28 days, a significant decrease was observed in the BS values $(\mathrm{p}=$ $0.0003)$, similar to the $30 \mathrm{~min}$ period $(\mathrm{p}=0.0564)$.

Table 1 Mean bond strength value (MPa) and standard deviation (SD) recorded for groups 1 and 2, in each period.

\begin{tabular}{lllll} 
& \multicolumn{2}{c}{$\begin{array}{c}\text { Group 1 } \\
\text { (Biodentine) }\end{array}$} & \multicolumn{2}{c}{$\begin{array}{c}\text { Group 2 } \\
\text { (Biodentine + PBS) }\end{array}$} \\
Period & Mean & SD & Mean & SD \\
\hline $\mathbf{3 0}$ min & $1.37^{\mathrm{aC}}$ & 0.41 & $0.32^{\mathrm{bB}}$ & 0.16 \\
$\mathbf{1}$ day & $8.06^{\mathrm{aB}}$ & 3.14 & $9.85^{\mathrm{aA}}$ & 7.36 \\
$\mathbf{3}$ days & $16.8^{\mathrm{aA}}$ & 7.60 & $9.97^{\mathrm{bA}}$ & 4.49 \\
$\mathbf{2 8}$ days & $7.77^{\mathrm{aB}}$ & 3.80 & $2.84^{\mathrm{bB}}$ & 1.38 \\
\hline Mean & $8.50^{\mathrm{a}}$ & 2.96 & $5.75^{\mathrm{b}}$ & 3.23
\end{tabular}

Same lowercase letter within the same row, and same uppercase letter within the same column indicate that the means are not statistically different $(p>0.05)$.

\section{Discussion}

The material used to seal communications between periodontium and the root canal should resist the forces that cause its displacement ${ }^{4}$.

The push-out test aims to assess the bond strength of a restorative material to dentin. Our study was designed to assess the resistance to dislodgement of Biodentine from dentinal wall.

The mean push-out BS values of both experimental groups are in agreement with previous studies ${ }^{4,9}$.

It is known that environment humidity is a factor that affects the properties of tricalcium silicate-based cements ${ }^{14}$. The setting conditions play an important role on the retention characteristics of MTA. Gancedo-Caravia and Garcia-Rabelo 
$(2006)^{5}$ showed that the push-out strength of dry-cured MTA is lower than that of wet-cured MTA. A study by Vizgirda et al. (2004) $)^{15}$ supports the importance of humidity for a proper curing of MTA, as the authors found that the MTA sealing was deficient when used to fill the entire length of the root canal and suggested that this may be caused by incomplete curing of MTA.

Another advantage of the humidity in contact with the tricalcium silicate-based cements is the release of the calcium hydroxide it contains ${ }^{5}$. This hydroxide may be responsible for the advantageous properties that cements have in contact with dental and periapical tissues ${ }^{11,16-17}$.

However Sluyk et al. $(1998)^{18}$ demonstrated no significant differences in the push-out strength of MTA set in dry environment and in the presence of humidity. Nevertheless, under real clinical conditions, a complete absence of humidity at side of the cement is not possible because the internal tissues always provide a wet environment at the external surface of the $\operatorname{root}^{5}$.

Then, as Biodentine has a composition similar powder to the MTA, it is expected that its shows similar values of BS when submitted to the push-out test.

Our study demonstrates that in humid environment (G1), the mean BS of Biodentine to dentin (8.5 MPa) was similar to that reported in other studies (7.18-8.79 $\mathrm{MPa})^{4,9}$ and higher than BS of MTA ${ }^{2-4,19}$.

It is known that when in contact with PBS, MTA presents higher BS values ${ }^{2-3}$, possibly due to formation of a carbonated apatite layer at the interface with dentin ${ }^{20}$. Biodentine is also able to interact with PBS and promote the biomineralization process ${ }^{13}$. Therefore, similar to what is observed for MTA, the interaction of Biodentine with PBS should lead to increase in the BS values. However, the data achieved in this study demonstrated that this interaction did not promote the expected increase. The presence of the modified polycarboxylate polymer in the Biodentine liquid, used as water reducing agent, may have contributed to this outcome ${ }^{21}$. This polymer is a dispersant widely used in civil engineering, being classified as a super-plastifying agent. When mixed with water, the cement grains tend to uptake part of the liquid. Polycarboxylate, acting as a dispersant, prevents this uptake and assures greater fluidity to the cement ${ }^{22}$. However, when in contact with PBS, it is possible that Biodentine has a greater quantity of water available, consequently presenting greater dispersion of particles, allowing the incorporation of air and facilitating the formation of pores, leading to cement displacement.

The calcium chloride $\left(\mathrm{CaCl}_{2}\right)$ present in the Biodentine liquid may also have affected its BS after exposure to PBS. When a cement containing tricalcium silicate is associated with $\mathrm{CaCl}_{2}$ smaller quantity of water is necessary for the mixture ${ }^{23}$, due to the hydration of silicates ${ }^{24}$ and the hygroscopic action of $\mathrm{CaCl}_{2}{ }^{25}$. The contact of Biodentine with PBS may have allowed greater water absorption by the cement, changing the powder-liquid ratio. When a cement containing tricalcium silicate is prepared with a powder-liquid ratio above the ideal, nearly all excess water favors the formation of pores and increases the material solubility ${ }^{14}$. Surprisingly, the results evidenced a significant decrease in BS at 28 days. Explanations for this observation should be further analyzed in other studies.

The exposure of Biodentine to PBS led to lower BS values. In general, the BS was gradually increased up to 3 days and reduced at 28 days.

\section{Acknowledgements}

The authors thank Septodont that kindly provided the Biodentine for this study. The authors deny any conflicts of interest related to this study.

\section{References}

1. Torabinejad M, Higa RK, McKendry DJ, Pitt Ford TR. Dye leakage of four root end filling materials: effects of blood contamination. JEndod. 1994; 20 : 159-63.

2. Reyes-Carmona JF, Felippe MS, Felippe WT. The biomineralization ability of mineral trioxide aggregate and Portland cement on detine enhances the push-out strength. J Endod. 2010; 36: 286-91.

3. de Almeida J, Felippe MCS, Bortoluzzi EA, Teixeira CS, Felippe WT. Influence of the exposure of MTA with and without calcium chloride to phosphate-buffered saline on the push-out bond strength to dentine. Int Endod J. 2013; 47: 449-53.

4. Guneser MB, Akbulut MB, Eldeniz AU. Effect of various endodontic irrigants on the push-out bond strength of Biodentine and conventional root perforation repair materials. J Endod. 2013; 39: 380-4.

5. Gancedo-Caravia L, Garcia-Barbero E. Influence of humidity and setting time on the push-out strength of mineral trioxide aggregate obturations. J Endod. 2006; 32: 894-6.

6. Rajasekharan S, Martens LC, Cauwels RGEC, Verbeeck RM. Biodentine ${ }^{\mathrm{TM}}$ material characteristics and clinical applications: a review of the literature. Eur Arch Pediatr Dent. 2014; 15: 147-58.

7. Laurent P, Camps J, De Meo M, Déjou J, About I. Induction of specific cell responses to a $\mathrm{Ca}(3) \mathrm{SiO}(5)$-based posterior restorative material. Dent Mater. 2008; 24: 1486-94.

8. Laurent P, Camps J, About I. Biodentine ${ }^{\mathrm{TM}}$ induces TGF-â1 release from human pulp cells and early dental pulp mineralization. Int Endod J. 2012; 45: 439-48.

9. El-Ma'aita AM, Qualtrough AJE, Watts DC. The effect of smear layer on the push-out bond strength of root canal calcium silicate cements. Dent Mater. 2013; 29: 797-803.

10. Colon P, Bronnec F, Grosgogeat B, Plasse-Pradelle N. Interactions Between a Calcium Silicate Cement (Biodentine) and Its Environment [abstract]. 2010 [cited 2012 May 12]. Available from: http://iadr.confex.com/ iadr/2010barce/preliminaryprogram/abstract_136289.htm.

11. Camilleri J, Sorrentino F, Damidot D. Investigation of the hydration and bioactivity of radiopacified tricalcium silicate cement, Biodentine and MTA Angelus. Dent Mater. 2013; 29: 580-93

12. Han L, Okiji T. Uptake of calcium and silicon released from calcium silicate-based endodontic materials into root canal dentine. Int Endod J. 2011; 44: 1081-7.

13. Han L, Okiji T. Bioactivity evaluation of three calcium silicate based endodontic materials. Int Endod J. 2013; 46: 808-14.

14. Fridland M, Rosado R. Mineral trioxide aggregate (MTA) solubility and porosity with different water-to-powder ratios. J Endod. 2003: 29; 814-7.

15. Vizgirda PJ, Liewehr FR, Patton WR, McPherson JC, Buxton TB. A comparison of laterally condensed gutta-percha, thermoplasticized guttapercha, and mineral trioxide aggregate as root canal filling materials. J Endod. 2004; 30: 103-6. 
16. Torabinejad M, Hong CU, Lee SJ, Monsef M, Pitt Ford TR. Investigation of mineral trioxide aggregate for root end filling in dogs. J Endod. 1995; 21 : 603-8.

17. Torabinejad M, Pitt Ford TR, McKendry DJ, Abedi HR, Miller DA, Kariyawasam SP. Histologic assessment of mineral trioxide aggregate as a root-end filling in monkeys. J Endod. 1997; 23: 225-8.

18. Sluyk SR, Moon PC, Hartwell GR. Evaluation of setting properties and retention characteristics of mineral trioxide aggregate when used as a furcation perforation repair material. J Endod. 1998; 24: 768-71.

19. Aggarwal V, Singla M, Miglani S, Kohli S.Comparative evaluation of push-out bond strength of ProRoot MTA, Biodentine, and MTA Plus in furcation perforation repair. J Conserv Dent. 2013; 16: 462-5.

20. Reyes-Carmona JF, Felippe MS, Felippe WT. Biomineralization ability and interaction of mineral trioxide aggregate and white Portland cement with detine in a phosphate-containing fluid. J Endod. 2009; 35: 731-6.

21. Grech L, Mallia B, Camilleri J. Investigation of the physical properties of tricalcium silicate cement-based root-end filling materials. Dent Mater. 2013; 29: 20-8.

22. Paillere AM. Application of admixtures in concrete. Rilem Report no. 10. UK: E \& FN Spon; 1995

23. Bortoluzzi EA, Broon NJ, Bramante CM, Garcia RB, Moraes IG, Bernardineli N. Sealing ability of MTA and radiopaque Portland cement with or without calcium chloride for root-end filling. J Endod. 2006; 32: 897900.

24. Ramachandran VS. Concrete admixtures handbook. Park Ridge, NJ: Noyes Publications; 1984.

25. Bortoluzzi EA, Broon NJ, Bramante CM, Felippe WT, Tanomaru-Filho M, Esberard RM. The influence of calcium chloride on the setting time, solubility, disintegration, and $\mathrm{pH}$ of mineral trioxide aggregate and white Portland cement with a radiopacifier. J Endod. 2009; 35: 550-4. 